\title{
SIMULASI PELIMPAHAN BEBAN PMT OUTGOING PWI O6 SAAT TERJADI OVERLOAD SHEDDING PADA TRAFO INCOMING 03 GARDU INDUK PURWODADI DENGAN MONITORING VT SCADA BERBASIS ARDUINO MEGA 2560
}

\author{
Reza Rizkifadhla, Heru Winarno \\ Program Studi D-III Teknik Elektro, Sekolah Vokasi, Universitas Diponegoro \\ Jl. Prof. Soedarto, SH, Kampus Undip Tembalang, Semarang, Indonesia 50275
}

\begin{abstract}
Reza Rizkifadhla, Heru Winarno, in this article explains that overload shedding in incoming transformer occurs due to an increase in load current that exceeds the capacity of the transformer. If overload shedding is not handled, it will cause damage to the transformer, and even cause incoming trip feeders and a very wide blackout effect. Relay overload shedding mounted on incoming feeders works to anticipate overload shedding by deliberately releasing outgoing feeders gradually to reduce the load. This study aims to provide a simulation of the conditions of incoming feeders during normal times, during overload shedding and handling of outgoing feeders deliberately released by carrying out load maneuvers to other feeders with different incoming transformers. Maneuvers are carried out to maintain the reliability of the continuity of electricity distribution. In this study one simulation tool was designed. The design of this tool uses a relay and Arduino Mega 2560 as a control center. Arduino Mega 2560 reads the current using the ZMCT 103C sensor. The simulation is based on the overload shedding event that has occurred in Purwodadi Substation. As for controlling switching equipment and monitoring current and voltage is done using HMI with VT Scada software. In the experiment, 3 incoming normal currents were 2.2 A with a load of 512 VAC 5 W lamps. Simulated maneuvering error, the load on incoming 3 increased to 2.60 A. This situation is considered to have reached the condition of overload shedding, relay PMT $C$ trip to reduce the load. Incoming 3 returns back to normal, namely 1.68 A. Loads on PMT C that are extinguished are maneuvered to PMT E or PMT F which have different incoming.
\end{abstract}

Keywords: reliability; overload shedding; maneuver

\section{PENDAHULUAN}

Listrik sudah menjadi kebutuhan primer bagi masyarakat di era modern ini. Banyak sektor yang bergantung pada energi listrik mulai dari sektor industri, komunikasi dan masih banyak lagi. Tanpa listrik maka aktivitas manusia akan lumpuh. Perkembangan penggunaan tenaga listrik semakin meningkat seiring perkembangan zaman yang semakian modern. Oleh karena itulah keandalan kontinuitas tenaga listrik harus tetap dijaga demi kepentingan bersama. Sistem Tenaga Listrik dikatakan sebagai kumpulan/gabungan yang terdiri dari komponen atau alat-alat listrik seperti generator, transformator, saluran transmisi, saluran distribusi dan beban yang saling berhubungan dan merupakan satu kesatuan sehingga membentuk suatu sistem[1]. PT. PLN (Persero) dituntut untuk menyediakan energi listrik yang cukup, baik secara kuantitas maupun kualitas. PT PLN (Persero) harus mampu melakukan peningkatan pelayanan dan penyediaan energi listrik yang andal, aman dan efisien. Listrik yang disalurkan ke pelanggan harus secara kontinyu, aman, dan efisien dalam biaya pengoperasianya. Dalam kenyatannya di lapangan, gangguan tetap tidak bisa dihindarkan secara mutlak dan menyebabkan pemadaman pelanggan. Pemadaman juga bisa dilakukan karena adanya pekerjaan PLN.
PLN berupaya untuk meminimalisir daerah padam sekecil mungkin baik itu yang diakibatkan oleh gangguan maupun dikarenakan adnya pekerjaan. Untuk itulah diperlukan sebuah tindakan pengoperasioan peralatan switching yang berada pada jaringan untuk memperkecil wilayah pemadaman. Untuk mendapatkan pemadaman yang sesuai dengan yang dibutuhkan diperlukan manuver jaringan. Manuver merupakan kegiatan sebelum dan sesudah pekerjaan instalasi, baik pada instalasi pembangkitan maupun penyaluran. Kegiatan maneuver berupa pembukaan atau penutupan komponen sistem tenaga listrik[2]. Manuver jaringan juga dapat memindahkan beban dari suatu penyulang ke penyulang lainnya dengan pertimbangan beban di setiap penyulangnya, tujuannya sama yaitu untuk mengurangi wilayah padam. Jika terjadi kesalahan manuver beban sangat dimungkinkan mengakibatkan Overload shedding pada trafo incoming. Gangguan beban lebih terjadi karena perubahan sistem distribusi yang melebihi kapasitas sistem terpasang. Gangguan ini sebenarnybukan gangguan murni, tetapi bila dibiarkan terus menerus berlangsung dapat merusak peralatan[3]. Beban trafo yang berlebih dapat mengakibatkan kerusakan pada trafo, bahkan dapat menyebabkan PMT incoming trip dan berimbas pemadaman yang sangat luas. Oleh karena itulah 
diperlukan proteksi beban lebih terhadap trafo yaitu Relay Overload Shedding (OLS). Relay Overload Shedding (OLS) merupakan proteksi yang dipasang pada trafo data incoming $20 \mathrm{kV}$ yang bekerja mematikan PMT outgoing secara bertahap apabila terjadi kelebihan beban. Pelepasan PMT outgoing dilakukan sebagai pencegahan dini sebelum trafo incoming trip karena melebihi kapasitasnya. Setelah itu, PMT outgoing yang dilepas akan di-manuver bebannya ke punyulang lain dengan trafo incoming yang berbeda secara remote oleh dispatcher. Dengan diterapkannya Relay Overload Shedding (OLS) pada Gardu Induk Purwodadi diharapkan dapat menjaga umur trafo dan keandalan kontinuitas tenaga listrik.

Pada penelitian ini dilakukan simulasi Pelimpahan Beban PMT Outgoing PWI 06 Saat Terjadi Overload Shedding Pada Trafo Incoming 03 Gardu Induk Purwodadi, yang hasilnya akan dimonitor dengan menggunakan sistem berbasis VT Scada dan Arduino Mega 2560, untuk menguji keandalan dan akurasi dari sistem, sehingga dapat digunakan sebagai prototipe laik industri.

\section{METODE PENELITIAN}

Secara konsep, alat ini simulator yang dirancang menyimulasikan kerja relay overload shedding pada penyulang incoming di Gardu Induk. Relay merupakan peralatan pengambil keputusan dalam sistem proteksi [6]. Dengan melihat masukan dari trafo instrumen dan mempertimbangkan setting yang diterapkan pada relay tersebut, maka relay dapat mengambil keputusan untuk memberi order trip atau tidak kepada peralatan pemutus (PMT)[4].

Alat simulator dirancang untuk menyimulasikan bagaimana terjadinya overload shedding pada trafo incoming 03 Gardu Induk Purwodadi dan bagaimana pelimpahan beban dilakukan sebagai tindak lanjut dari terjadinya overload shedding [7]. Alat simulator yang dibuat berupa peralatan miniatur sebagai pengganti perangkat sebenarnya di lapangan. Blok diagram alat simulator dapat dilihat pada gambar 1 .

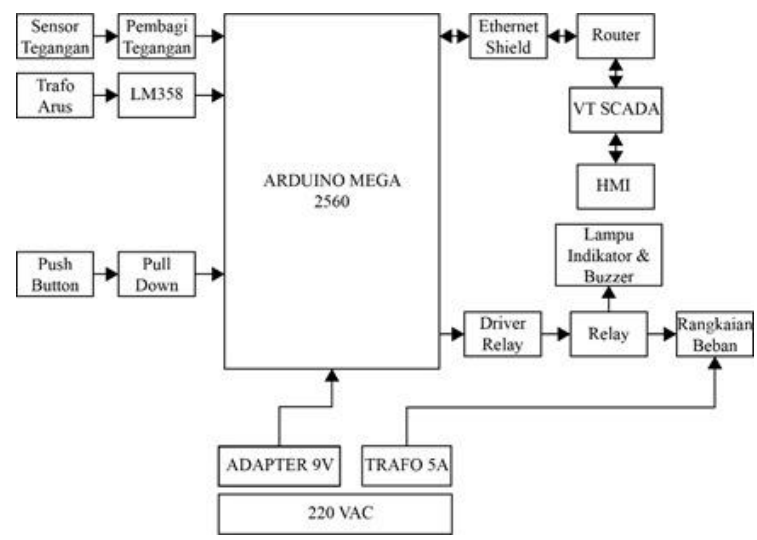

Gambar 1. Blok Diagram Alat Simulasi

Bagian-bagian dari blok diagram tersebut dapat dijelaskan sebagai berikut :
1. Sumber tegangan PLN 220 VAC digunakan untuk input trafo stepdown pertama. Trafo stepdown pertama menurunkan tegangan dari 220 VAC menjadi 12 VAC. Tegangan output dari trafo stepdown sebesar 12 VAC digunakan untuk supply beban pada alat simulator, beban terhubung dengan sensor tegangan dan sensor arus untuk dimonitoring besar arus dan tegangannya. Sensor tegangan berupa rangkaian pembagi tegangan sebagai pendeteksi besar tegangan beban yang terhubung dengan Arduino. Sensor arus mendeteksi besar arus beban dan memberikan besaran ADC (Analog Digital Converter) ke Arduino. Arduino akan mengolah data dari sensor dan mengonversinya menjadi besaran ampere dan volt. Besar arus dan tegangan ditampilkan di HMI dengan perantara komunikasi Ethernet Shield.

2. Sumber tegangan PLN 220 VAC digunakan sebagai input trafo stepdown kedua. Trafo stepdown kedua menurunkan tegangan dari 220 VAC menjadi $25 \mathrm{VAC}$ dan $12 \mathrm{VAC}$. Tegangan 25 VAC digunakan sebagai input catu daya 24 VDC disearahkan melalui dioda dan diatur tegangannya menggunakan IC LM 7824. Tegangan 12 VAC digunakan sebagai input catu daya 12 VDC disearahkan melalui dioda dan diatur tegangannya menggunakan IC LM 7812. Tegangan 12 VDC yang dihasilkan catu daya digunakan untuk mencatu pilot lamp sebagai indikator open close relay dan buzzer sebagai alarm. Tegangan 24 VDC dari catu daya digunakan untuk mencatu relay dan driver relay. Relay terhubung dengan rangkaian beban, indikator (pilot lamp) dan buzzer. Kondisi relay Normally Close atau Normally Open dapat dikontrol melalui Arduino. Arduino mengontrol relay dengan perantara driver relay.

3. Sumber PLN 220 VAC digunakan sebagai input adaptor 9V yang digunakan untuk mensupply Arduino. Tegangan output 5 VDC dari Arduino digunakan untuk mencatu rangkaian push button pulldown dan sensor arus. Rangkaian pull down merupakan rangkaian yang berfungsi untuk mengatur sinyal dari push button sebelum memasuki mikrokontroler, agar sinyal tidak mengalami floating yang dapat menyebabkan kesalahan pembacaan pada arduino.

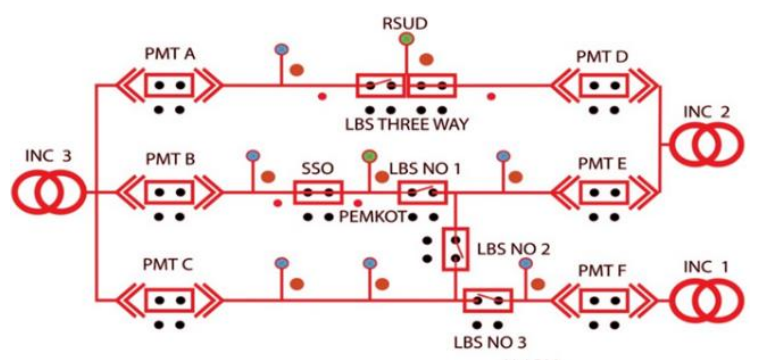

Gambar 2. Single Line Diagram Alat Simulasi 
Gambar 2 merupakan single line diagram alat simulasi. Komponen dan peralatan yang digunakan pada alat simulasi ini berfungsi sebagai pengganti peralatan sistem pada peralatan Gardu Induk $20 \mathrm{KV}$ yang sebenarnya. Sumber DC pada Gardu Induk digantikan oleh catu daya. Peralatan Switcing di lapangan berupa PMT dan LBS digantikan oleh relay. Kontrol peralatan switching secara local digantikan oleh push button yang terhubung dengan rangkaian pull down. Alarm gangguan digantikan oleh buzzer. Potential Transformer digantikan oleh sensor tegangan. Current Trnasformer digantikan oleh sensor ZMCT 103C. Beban diasumsikan oleh lampu 12 VAC 5W. Relay Overload Shedding sebagai pusat control diasumsikan oleh Arduino Mega 2560. Pengoperasian peralatan switching secara remote dan monitoring arus dan tegangan dilakukan menggunakan VT Scada sebagai pengganti World View di PT PLN (Persero).

Supervisory Control And Data Acquisition atau sering kita kenal dengan SCADA adalah sistem kendali industri berbasis komputer yang dipakai untuk monitoring system atau control system. VT Scada merupakan software SCADA yang diproduksi oleh Trihedral Engineering yang memiliki awalnya bernama WEB. WEB sistem operasi yang berbasis HMI memiliki bahasa scripting untuk tags, page, dan yang berhubungan dengan SCADA dibuat melalui penulisan kode. Kemudian pada tahun 1995, WEB berganti nama menjadi VTS (Visual Tag System) karena program tersbut mengalami perkembangan dalam hal GUI (Graphic User Interface) yang membuat lebih mudah dalam penggunaan apikasi SCADA[5].

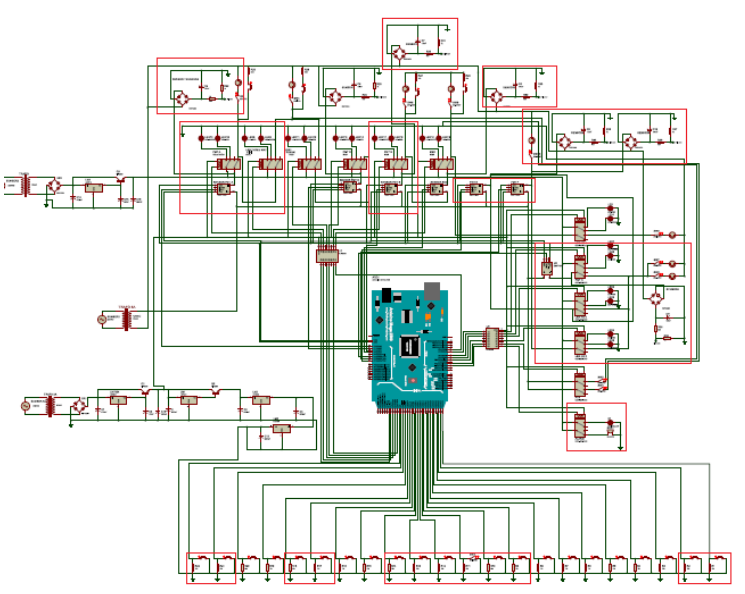

Gambar 3. Rangkaian Keseluruhan Alat Simulasi

Gambar 3 merupakan rangkaian keseluruhan alat simulasi. Cara kerja rangkaian keseluruhan dalam simulator ini dimulai dari sumber tegangan PLN 220 VAC digunakan untuk input trafo stepdown pertama. Trafo stepdown pertama menurunkan tegangan dari 220 VAC menjadi 12 VAC. Tegangan output dari trafo stepdown sebesar 12 VAC digunakan untuk supply beban pada alat simulator yang berupa lampu $12 \mathrm{~V} / 5$ Watt yang disusun secara paralel.
Sumber tegangan PLN 220 VAC juga masuk sebagai input transformator stepdown kedua yang digunakan sebagai penurun tegangan dari 220 VAC menjadi 24 VAC dan 12 VAC. Tegangan output pada trafo stepdown kedua sebesar $24 \mathrm{VAC}$ dan $12 \mathrm{VAC}$ digunakan sebagai tegangan input catu daya 24 VDC dan 12 VDC. Catu daya digunakan untuk menyearahkan arus bolak-balik (AC) menjadi arus searah (DC). Penyearahan arus ini dimulai dari 4 buah dioda yang disusun membentuk rangkaian penyearah gelombang penuh. Keluaran dari penyearah gelombang penuh, masih menghasilkan tegangan DC denyut yang masih memiliki ripple. Untuk mengurangi faktor ripple digunakan kapasitor elco (sebesar $4700 \mu \mathrm{F}, 100 \mu \mathrm{F}$ dan $1000 \mu \mathrm{F}$ ) sehingga dihasilkan tegangan DC dengan gelombang yang lebih halus (low ripple). Setelah dihasilkan gelombang DC low ripple tegangan masuk ke IC regulator untuk dibatasi tegangaan keluarannya sesuai tegangan referensi. Voltage regulator dapat menghasilkan output tegangan yang stabil. Berdasarkan datasheet, IC LM7824 dan IC LM7812 hanya mempunyai arus keluaran maksimal sebesar 1 Ampere maka setiap output kaki IC Regulator akan dialirkan ke transistor NPN TIP 3055 yang berfungsi sebagai penguat arus. TIP 3055 memiliki kapasitas arus mencapai 15 Ampere.

Output dari catu daya 24 VDC digunakan sebagai supply driver relay, dan relay. Output dari catu daya 12 VDC digunakan sebagai supply indikator pilot lamp dan buzzer. Tegangan 5V dari pin out Arduino dimanfaatkan sebagai input rangkaian push button pulldown dan sensor arus ZMCT 103C.

Awal sistem dimulai dari menghidupkan saklar beban untuk menghidupkan beban dan saklar kontrol untuk menghidupkan rangkaian kontrol. Beban dapat dikontak dengan relay dengan memanfaatkan push button. Push button pada alat simulasi tersupply oleh 5 VDC dan terhubung dengan rangkaian pull down. Rangkaian pull down tersebut terhubung dengan Arduino. Rangkaian push button pull down memiliki konsep utama dimana saat keadaan push button pada rangkaian ditekan atau dihubungkan maka akan menghasilkan output yang bernilai high (+-5V) yang dibaca Arduino, sedangkan saat keadaan terbuka atau putus output yang dihasilkan oleh rangkaian tersebut akan bernilai low (0V) yang dibaca oleh Arduino.

Dari masukan push button ini akan diolah melalui Arduino. Arduino dapat mengontak relay melalui pin digital yang terhubung dengan input rangkaian driver relay. Arduino dapat memberi logika high (+-5V) pada input driver relay yang menyebabkan Transistor Darlington pada driver relay bekerja dan tegangan yang sudah masuk ke driver relay sebesar $24 \mathrm{~V}$ masuk ke coil relay dan relay MY2N jenis DPDT (Double Pole Double Throw) dapat mengontak. Relay DPDT memungkinkan dua pengoperasian switching secara bersamaan, dalam alat simulasi ini relay berperan menghubungkan dan 
memutuskan rangkaian beban bersamaan dengan indikator (pilot lamp).

Sensor Arus ZMCT $103 \mathrm{C}$ yang berperan sebagai perangkat monitoring arus pada alat simulasi ini mendapatkan masukan sebesar 5 VDC dari Arduino. Pin Out sensor arus ZMCT 103 C dihubungkan dengan Arduino melalui pin analognya. Sensor arus ZMCT 103C akan mengirimkan hasil pembacaan kepada Arduino Mega 2560. Arduino akan membaca input dari sensor arus ZMCT 103 C, mengolah data ADC sensor menjadikan besaran ampere dan menampilkannya pada HMI.

Sensor tegangan berperan memonitoring tegangan pada beban. Tegangan kerja beban sebesar 12 VAC kemudian disearahkan menggunakan dioda bridge dan di filter dengan kapasitor. Output dari kapasitor yang sudah berupa tegangan DC akan dibagi tegangannya menggunakan pembagi tegangan. Output dari pembagi tegangan terhubung dengan pin analog arduino untuk dibaca dan diolah. Arduino akan menampilkan besaran volt tegangan kerja rangkaian beban pada HMI.

HMI pada alat simulasi ini akan menampilkan besaran arus pada setiap PMT outgoing dan trafo incoming. Besaran tegangan pada setiap PMT outgoing juga akan ditampilkan pada HMI. Pembahasan penelitian ini berupa pelimpahan beban pada PMT C akibat arus pada incoming 3 melebihi batas normal karena overload shedding.

Trafo incoming 03 pada alat simulasi, dianggap memiliki kapasitas sebagai berikut:

Daya Terpasang : $50 \mathrm{VA}$

Rasio Tegangan: 220V/12V

Dari data tersebut dapat diperoleh arus setting overload shedding. Setting arus Overload shedding diatur berdasarkan arus nominal maksimal pada sisi low voltage trafo, dengan perhitungan sebagai berikut:

$$
\begin{aligned}
& \text { Is }=\mathrm{S} /(\mathrm{V} . \sqrt{ } 3) \\
& \text { Is }=50 \mathrm{VA} /(12 \mathrm{~V} .1,732 \mathrm{~A}) \\
& \text { Is }=2,4 \mathrm{~A}
\end{aligned}
$$

Jadi, jika arus pada penyulang incoming 3 lebih dari 2,4 A overload shedding akan terjadi dan PMT C akan trip sebagai akibat dari bekerjanya relay overload shedding pada trafo incoming 03.

Pada alat simulasi ini digunakan beban lampu $12 \mathrm{~V} 5 \mathrm{~W}$. Tengangan kerja rangkaian beban pada alat simulasi sebesar 12 VAC. Gambar 4 adalah kondisi beban incoming 3 saat keadaan normal.

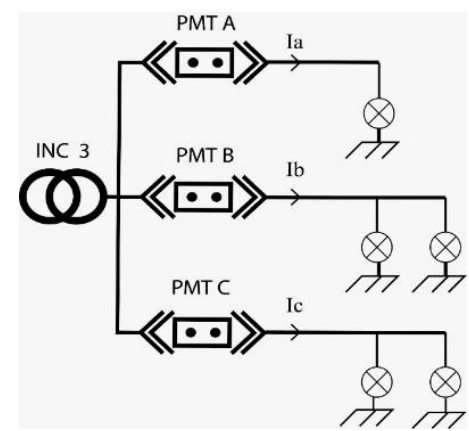

Gambar 4. Kondisi beban incoming 3 saat keadaan normal

Pada keadaan normal trafo incoming 3 mensupply PMT A, PMT B dan PMT C. Berikut perhitungan arus beban pada masing masing penyulang outgoing:

Perhitungan nilai arus beban setiap lampu :

$\mathrm{P}$ lampu $=5 \mathrm{~W}$

$\mathrm{V}$ lampu $=12 \mathrm{~V}$

Untuk mendapatkan nilai I, digunakan rumus daya seperti berikut ini

$\mathrm{P}=\mathrm{V}$.I

$\mathrm{I}_{\text {lampu }}=\mathrm{P}_{\text {lampu }} / \mathrm{V}_{\text {lampu }}$

$\mathrm{I}_{\mathrm{lampu}}=5 / 12$

$\mathrm{I}_{\text {lampu }}=0,42 \mathrm{~A}$

Perhitungan nilai arus beban setiap PMT Outgoing :

$\mathrm{Ia}=1 \times \mathrm{I}_{\text {lampu }}=1 \times 0,42 \mathrm{~A}=0,42 \mathrm{~A}$

$\mathrm{Ib}=2 \times \mathrm{I}_{\mathrm{lampu}}=2 \times 0,42 \mathrm{~A}=0,84 \mathrm{~A}$

Ic $=2 \times \mathrm{I}_{\text {lampu }}=2 \times 0,42 \mathrm{~A}=0,84 \mathrm{~A}$

Nilai arus incoming 3 adalah penjumlahan dari arus beban PMT A, arus beban PMT B dan arus beban PMT C

Arus beban incoming $3=\mathrm{Ia}+\mathrm{Ib}+\mathrm{Ic}$

$$
=0,42+0,84+0,84
$$

$$
=2,1 \mathrm{~A}
$$

Arus beban incoming $3=2,1 \mathrm{~A}$

Arus beban incoming $3<2,4 \mathrm{~A}$

Pada keadaan ini, incoming 3 masih mampu mensupply beban secara kontinyu karena batas overload shedding sebesar 2,4 A.

Disimulasikan gangguan pada PMT D yang mengakibatkan beban pada PMT D padam. Sebagai tindak lanjut dari adanya pemadaan beban pada PMT $\mathrm{D}$, maka dilakukan manuver beban PMT D ke PMT A dengan mengoperasikan LBS threeways. Manuver tersebut mengakibatkan PMT A mendapatkan beban tambahan dari PMT D. Manuver yang dilakukan juga berimbas pada bertambahnya beban Incoming 3 sebagai supply PMT A. Gambar 5 adalah kondisi beban incoming 3 saat keadaan overload shedding. 


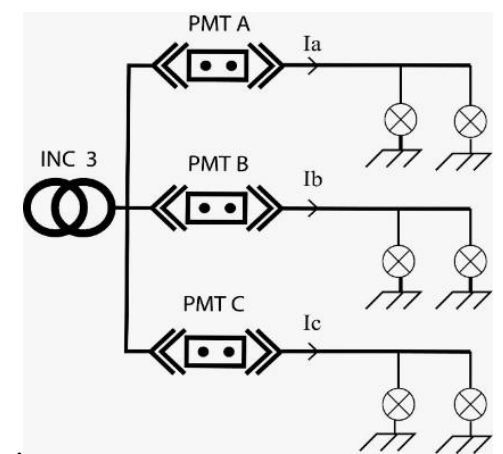

Gambar 5. Kondisi beban incoming 3 saat keadaan overload shedding

Perhitungan nilai arus beban setiap PMT Outgoing :

$\mathrm{Ia}=2 \times \mathrm{I}_{\mathrm{lampu}}=2 \times 0,42 \mathrm{~A}=0,84 \mathrm{~A}$

$\mathrm{Ib}=2 \times \mathrm{I}_{\text {lampu }}=2 \times 0,42 \mathrm{~A}=0,84 \mathrm{~A}$

$\mathrm{Ic}=2 \times \mathrm{I}_{\text {lampu }}=2 \times 0,42 \mathrm{~A}=0,84 \mathrm{~A}$

Nilai arus incoming 3 adalah penjumlahan dari arus beban PMT A, arus beban PMT B dan arus beban PMT C

Arus beban incoming $3=\mathrm{Ia}+\mathrm{Ib}+\mathrm{Ic}$

$$
=0,84+0,84+0,84
$$$$
=2,52 \mathrm{~A}
$$

Arus beban incoming $3=2,52 \mathrm{~A}$

Arus beban incoming $3>2,4 \mathrm{~A}$

Pada keadaan ini arus total pada incoming 3 mencapai 2,52 A. Relay overload shedding akan bekerja dan memerintahkan PMT C untuk trip. Gambar 6 adalah kondisi beban incoming 3 setelah relay overload shedding bekerja.

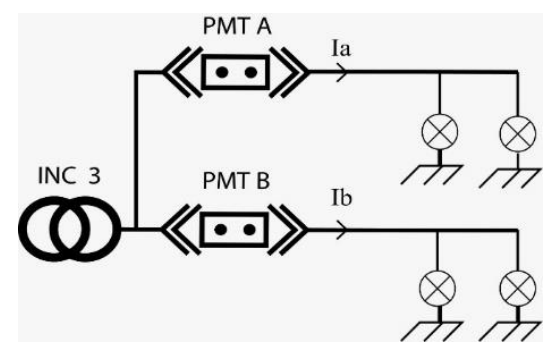

Gambar 6. kondisi beban incoming 3 setelah relay overload shedding bekerja

Perhitungan nilai arus beban setiap PMT Outgoing :

$\mathrm{Ia}=2 \times \mathrm{I}_{\text {lampu }}=2 \times 0,42 \mathrm{~A}=0,84 \mathrm{~A}$

$\mathrm{Ib}=2 \times \mathrm{I}_{\text {lampu }}=2 \times 0,42 \mathrm{~A}=0,84 \mathrm{~A}$

Nilai arus incoming 3 adalah penjumlahan dari arus beban PMT A, arus beban PMT B dan arus beban PMT C

Arus beban incoming $3=\mathrm{Ia}+\mathrm{Ib}$

$$
\begin{aligned}
& =0,84+0,84 \\
& =1,68 \mathrm{~A}
\end{aligned}
$$

Arus beban incoming $3=1,68 \mathrm{~A}$

Arus beban incoming $3<2,4 \mathrm{~A}$
Pada keadaan ini, incoming 3 sudah kembali normal karena batas overload shedding sebesar 2,4 A. Saat beban pada PMT C sudah padam, incoming 3 melepas beban sebesar 0,84 A pada PMT C sehinga pada keadaan ini arus yang melewati incoming 3 hanya sebesar 1,68 A. Untuk menjaga kontinuitas penyaluran tenaga listrik, beban pada PMT C yang padam harus dimanuver ke penyulang lain yang berbeda trafo incomingnya. Sebelum manuver beban dilakukan, harus dipastikan penyulang outgoing dan trafo incoming tertuju mampu menopang beban tambahan sebesar 0,84 A dari PMT C

Trafo Incoming 01 dan Trafo Incoming 02 pada alat simulasi dianggap memiliki kapasitas sebesar 50 VA sama seperti Trafo Incoming 03. Jadi, arus maksimal yang diijinkan melewati trafo incoming 01 atau trafo incoming 02 adalah 2,4 A.

Saat akan melakukan manuver beban PMT C sebesar 0,84 A ke penyulang yang bersumber dari trafo incoming 01 atau trafo incoming 02 yang mempunyai kapasitas maksimal arus 2,4 A, maka besar arus pada trafo incoming 01 atau trafo incoming 02 sebelum dilakukan manuver harus kurang dari 1,56 A. Manuver hanya dapat dilakukan saat penambahan beban sebesar 0,84 A dari PMT C trafo incoming masih mampu mensupplynya untuk menghindari overload shedding terjadi pada trafo incoming.

Keadaan sebelum beban PMT C dimanuver, Trafo incoming 01 hanya mensupply PMT E dengan beban satu lampu 0,42 A dan trafo incoming 02 hanya mensupply PMT F dengan beban satu lampu 0,42A. Trafo incoming 01 dan trafo incoming 02 berbeban kurang dari 1,56 A sehingga keduanya memenuhi persyaratan untuk dilakukan penambahan beban sebesar 0,84 A dari PMT C.

Jika dilakukan manuver ke trafo incoming 1, maka LBS NO 3 diperintahkan untuk close. Beban pada PMT C dilimpahkan ke PMT F. Arus kerja pada trafo incoming 1 menjadi 1,26 A. Pada keadaan ini semua beban sudah tersupply kembali dan overload shedding yang terjadi pada trafo incoming 3 sudah teratasi.

Jika dilakukan manuver ke trafo incoming 2, maka LBS NO 2 diperintahkan untuk close. Beban pada PMT C dilimpahkan ke PMT E. Arus kerja pada trafo incoming 2 menjadi 1,26 A. Pada keadaan ini semua beban sudah tersupply kembali dan overload shedding yang terjadi pada trafo incoming 3 sudah teratasi. Diagram alir alat simulasi ditunjukkan pada gambar 7 . 


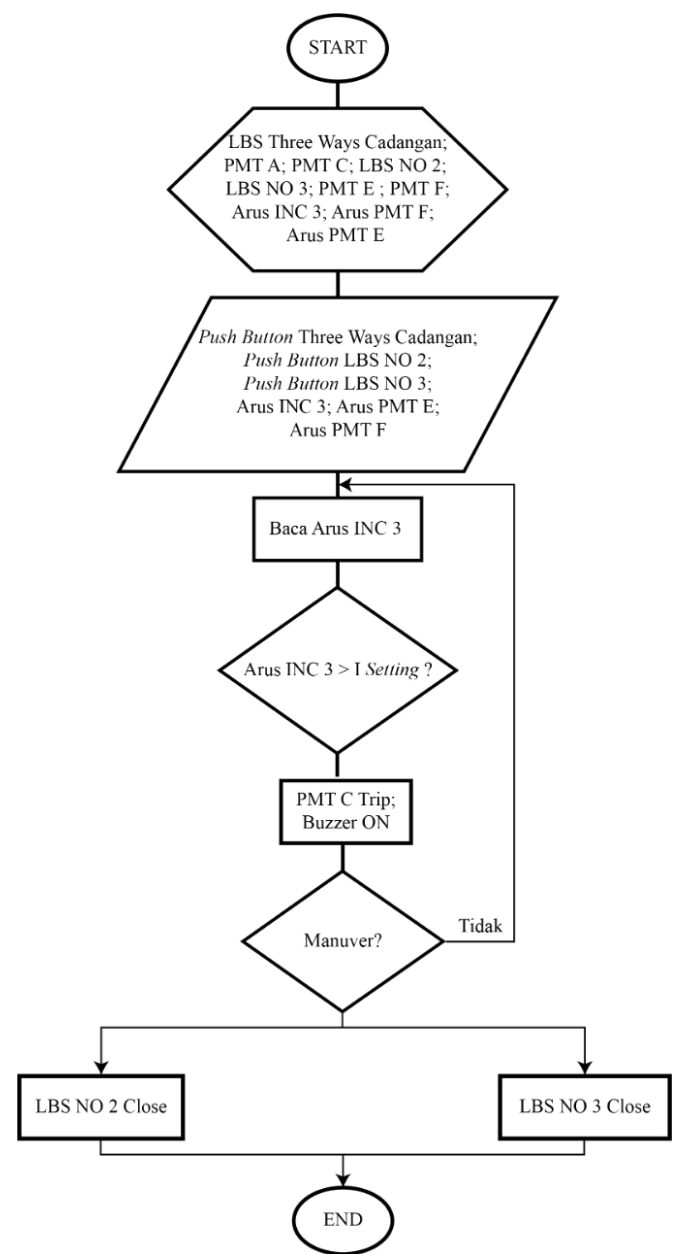

Gambar 7. Diagram Alir Alat Simulasi

\section{HASIL DAN PEMBAHASAN}

Pengujian dilakukan dengan menghubungkan seluruh perangkat beserta isinya, baik itu hardware dan software. Tujuan dari percobaan alat secara keseluruhan adalah untuk mengetahui apakah kerja dari simulasi alat penelitian ini sudah dapat berfungsi dan sesuai dengan yang direncanakan.

Pengujian dilakukan dalam 3 tahap yaitu tahap ketika keadaaan normal, keadaaan overload shedding dan keaadaan penormalan setelah dilakukan manuver beban.

Keadaan normal, semua lampu menyala. PMT A, PMT B, PMT C, PMT D, Load Break Switch (LBS) Three Ways Kanan dalam keadaan NC (Normally Close), dan Load Break Switch (LBS) Three Ways Kiri, LBS NO 2 dan LBS NO 3 dalam keadaan NO (Normally Open). Hasil pengujian arus pada kondisi normal ditunjukkan pada tabel 1 .

Dari tabel 1. berdasar arus pembacaan scada dapat diketahui bahwa nilai arus dari PMT A sebesar 0,40 A dengan beban 1 lampu yang menyala. Arus pada PMT B dengan beban 2 lampu sebesar 0,87 A. Arus pada PMT C dengan 2 lampu sebesar 0,92 A. Total Arus pada INC 3 sebesar 2,19 A.

Saat sistem sudah berjalan normal, pada PMT D diberi gangguan. Saat diberi gangguan PMT
D akan mengalami kenaikan arus melebihi nilai arus setting yang akan menyebabkan PMT D trip. Setelah itu melakukan manuver beban PMT D ke PMT A secara local atau remote. Karena pelimpahan beban, Incoming 3 terjadi Overload Shedding terjadi dan PMT C trip. Hasil pengujian arus pada kondisi overload shedding ditunjukkan pada tabel 2.

Tabel 1. Hasil Pengujian Arus Pada Kondisi Normal

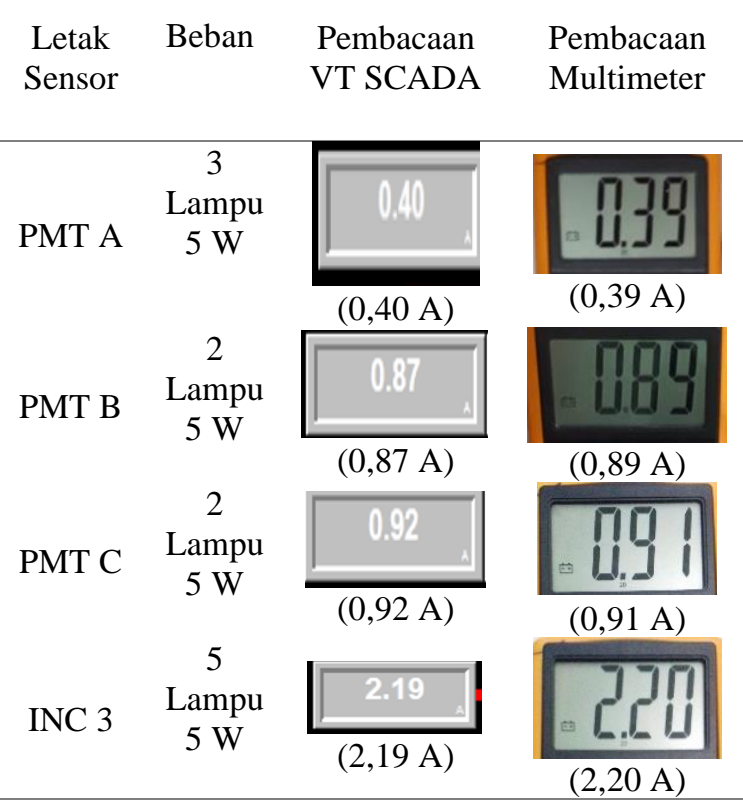

Tabel 2. Hasil Pengujian Arus Kondisi Overload Shedding

\begin{tabular}{|c|c|c|c|}
\hline $\begin{array}{l}\text { Letak } \\
\text { Sensor }\end{array}$ & Beban & $\begin{array}{l}\text { Pembacaan } \\
\text { VT SCADA }\end{array}$ & $\begin{array}{l}\text { Pembacaan } \\
\text { Multimeter }\end{array}$ \\
\hline PMT A & $\begin{array}{c}2 \\
\text { Lampu } \\
5 \mathrm{~W}\end{array}$ & $(0,80 \mathrm{~A})$ & $(0,7$ \\
\hline PMT B & $\begin{array}{c}2 \\
\text { Lampu } \\
5 \mathrm{~W}\end{array}$ & $\begin{array}{c}0.91 \\
(0,91 \mathrm{~A})\end{array}$ & $(0,91 \mathrm{~A})$ \\
\hline PMT C & $\begin{array}{c}2 \\
\text { Lampu } \\
5 \mathrm{~W}\end{array}$ & $\begin{array}{c}0.86 \\
(0,86 \mathrm{~A})\end{array}$ & $(0,89 \mathrm{~A})$ \\
\hline INC 3 & $\begin{array}{c}6 \\
\text { Lampu } \\
5 \mathrm{~W}\end{array}$ & \begin{tabular}{|c|}
2,59 \\
$(2,59 \mathrm{~A})$
\end{tabular} & $(2,60 \mathrm{~A})$ \\
\hline
\end{tabular}

Dapat dilihat dari tabel 1 dan table 2 berdasarkan pembacaan scada arus pada INC 3 mengalami kenaikan arus sebesar 0,40 A akibat 
pelimpahan beban dari PMT D menuju PMT A. Overload Shedding terjadi dan PMT C trip.

Saat overload shedding PMT C akan trip dan beban pada PMT $\mathrm{C}$ tidak tersupply. Oleh karena itulah dipeerlukan manuver beban PMT C. Manuver dapat dilakukan ke penyulang yang berbeda trafo incomingnya. Terdapat dua pilihan saat akan melakukan manuver beban. Pilihan pertama manuver beban ke PMT E (incoming 2) dengan menutup LBS NO 2. Piliham kedua manuver beban ke PMT F (incoming 1). Hasil pengujian arus setelah dilakukan maneuver beban PMT C ke PMT E ditunjukkan pada tabel 3. Hasil pengujian arus setelah dilakukan maneuver beban PMT C ke PMT F ditunjukkan pada tabel 4.

Tabel 3. Hasil Pengujian Arus Setelah dilakukan manuver beban PMT C ke PMT E

\begin{tabular}{|c|c|c|c|}
\hline $\begin{array}{l}\text { Letak } \\
\text { Sensor }\end{array}$ & Beban & $\begin{array}{l}\text { Pembacaan } \\
\text { VT SCADA }\end{array}$ & $\begin{array}{l}\text { Pembacaan } \\
\text { Multimeter }\end{array}$ \\
\hline \multirow{2}{*}{$\begin{array}{l}\text { PMT } \\
\text { C }\end{array}$} & (trip) & 0.01 & \\
\hline & & $(0,01 \mathrm{~A})$ & $(0,00 \mathrm{~A})$ \\
\hline \multirow{2}{*}{$\begin{array}{l}\text { PMT } \\
\text { E }\end{array}$} & $\begin{array}{c}3 \\
\text { Lampu }\end{array}$ & 1.33 & \\
\hline & $5 W$ & $(1,33 \mathrm{~A})$ & $(1,35 \mathrm{~A})$ \\
\hline \multirow[t]{2}{*}{ INC 3} & $\begin{array}{c}4 \\
\text { Lampu }\end{array}$ & 1.72 & \\
\hline & $5 \mathrm{~W}$ & $(1,72 \mathrm{~A})$ & $(1,68 \mathrm{~A})$ \\
\hline
\end{tabular}

Tabel 4. Hasil Pengujian Arus Setelah dilakukan manuver beban PMT C ke PMT F

\begin{tabular}{|c|c|c|c|}
\hline $\begin{array}{l}\text { Letak } \\
\text { Sensor }\end{array}$ & Beban & $\begin{array}{l}\text { Pembacaan } \\
\text { VT SCADA }\end{array}$ & $\begin{array}{l}\text { Pembacaan } \\
\text { Multimeter }\end{array}$ \\
\hline \multirow{2}{*}{ PMT C } & (trin) & 0.01 & \\
\hline & & $(0,01 \mathrm{~A})$ & $(0,0$ \\
\hline \multirow[t]{2}{*}{ PMT F } & $\begin{array}{c}3 \\
\text { Lampu }\end{array}$ & 1.36 & \\
\hline & $5 \mathrm{~W}$ & $(1,36 \mathrm{~A})$ & $(1,35 \mathrm{~A})$ \\
\hline \multirow[t]{2}{*}{ INC 3} & $\begin{array}{c}4 \\
\text { Lampu }\end{array}$ & 1.72 & \\
\hline & $5 \mathrm{~W}$ & $(1,72 \mathrm{~A})$ & $(1,68 \mathrm{~A})$ \\
\hline
\end{tabular}

Dengan dilakukan manuver maka beban pada PMT C sudah tersupply kembali, keadan kembali normal, kontinuitas penyaluran tenaga listrik terpenuhi.

\section{KESIMPULAN}

Overload Shedding pada trafo incoming dapat terjadi karena trafo incoming menyupply beban yang melebihi kapasitasnya. Saat Overload Shedding terjadi, Relay Overload Shedding akan bekerja dan memerintahkan salah satu penyulang outgoing trip untuk mengurangi beban pada trafo incoming. Dalam alat simulasi yang dirancang untuk penelitian ini Overload Shedding terjadi pada incoming 3 karena kesalahan manuver beban PMT D ke PMT A yang mengakibatkan relay PMT C trip. Arduino berperan sebagai pusat control pengolahan data dan pengendali sistem mendapatkan data input dari sensor arus ZMCT 103C yang terpasang pada setiap relay PMT. Arduino mampu mengendalikan relay sehingga sistem simulasi pada alat ini bisa berjalan.

Manuver beban PMT Outgoing yang trip saat terjadi Overload Shedding hanya dapat dilakukan ke penyulang lain yang berbeda trafo incomingnya karena trafo incoming yang mengalami Overload Shedding sudah tidak mampu lagi menyupply beban. Manuver beban dilaksanakan demi menjaga kontinuitas penyaluran tenaga listrik. Dalam alat simulasi ini, manuver beban PMT C yang trip akibat overload shedding pada incoming 3 dilakukan ke PMT E yang di supply incoming 2 atau PMT F yang di supply incoming 1 .

Sensor arus ZMCT 103C menggunakan trafo arus untuk membaca arus dari beban. Trafo arus pada ZMCT terhubung dengan rangkaian pengondisi sinyal. Rangkaian Pengondisi sinyal berperan sebagai penguat sinyal untuk kemudian mampu memberikan data ADC pada Arduino sesuai dengan arus yang di monitoring. Jika arus yang di monitoring berubah ADC yang dikirimkan sensor ke Arduino juga berubah. Arduino akan menerima data ADC dari sensor melalui pin Analognya, kemudian mengolahnya menjadi besaran ampere. Sebagai contoh, beban pada relay PMT C sebesar 0,92 A. Sensor arus ZMCT pada relay PMT $\mathrm{C}$ akan mengirimkan ADC sebesar 237 ke Arduino. Arduino mengubah besaran ADC tersebut ke dalam besaran voltage yaitu sebesar $1,16 \mathrm{~V}$. Setelah menjadi besaran voltage, arduino akan mengalikan dengan konstanta tertentu sebagai kalibrasi, konstanta kalibrasi pada sensor arus relay PMT C sebesar 0,791. Setelah hasil voltage di kalikan dengan konstanta maka menghasilkan besaran ampere yang dimonitoring sensor yaitu sebesar 0,92 A.

Sensor tegangan berupa rangkaian penyearah dan rangkaian pembagi tegangan. Sensor tegangan mendapat input dari beban $\mathrm{AC}$, disearahkan kemudian dibagi tegangannya untuk dibaca arduino. Arduino akan mengolah data masukan sensor tersebut menjadi besaran volt yang sebenarnya. Sebagai contoh tegangan kerja beban sebesar 12 VAC, setelah disearahkan dengan diode tegangan menjadi 16 VDC kemudian pembagi tegangan dengan $R$ 
sebesar $1 \mathrm{k}$ dan $3,3 \mathrm{k}$ akan membagi tegangan tersebut menjadi 3,72 VDC. Tegangan tersebut akan dibaca Arduino dan dikali dengan konstanta tertentu sebagai kalibrasi, dalam alat simulasi ini konstanta sebesar 3,22 . Setelah voltage yang dibaca arduino dikali dengan konstanta akan menghasilkan besaran voltage kerja yang di monitoring sensor.

Sensor arus ZMCT 103C mendeteksi arus pada beban, sensor tegangan mendeteksi tegangan pada beban. Kedua sensor tersebut menjadi input Arduino Mega 2560.Arduino terhubung dengan Ethernet Shield yang terhubung ke router. Arduino akan mengolah inputan sensor tersebut, mengirimkannya ke HMI melalui jaringan LAN. Besaran arus dan tegangan akan ditampilkan melalui VT SCADA. VT SCADA juga bisa mengontrol Arduino dengan memanfaatkan Mudbus. Saat dikontrol menggunakan Mudbus Arduino dapat mengontrol peralatan switching yang terhubung dengan beban.

Dalam alat simulasi ini, pada kondisi normal incoming 3 menyupply beban dengan arus 2,2 A. Setelah disimulasikan kesalahan maneuver beban, incoming 3 mendapat beban berlebih yang dikategorikan dalam keadaaan overload shedding yaitu sebesar 2,6 A. Relay PMT C trip karena overload shedding. Setelah PMT C trip beban incoming 3 berkurang menjadi 1,68 A. Beban pada relay PMT C yang padam, dimanuver ke penyulang lain yang berbeda incomingnya.

\section{UCAPAN TERIMA KASIH}

Terimakasih kepada PSDIII Teknik Elektro dan supervisor proteksi PLN UP2D Jateng DIY DCC Semarang beserta jajarannya yang sangat membantu pengumpulan data dan terlaksananya penelitian ini.

\section{DAFTAR PUSTAKA}

[1] Jasa Pendidikan dan Pelatihan. Sistem Distribusi Tenaga Listrik. PT. PLN (Persero) Pujotomo, I., 2016.

[2] Yuwono, Teguh. 2016. Sistem Operasi Tenaga Listrik. Semarang. Universitas Diponegoro.

[3] Sarimun, Wahyudi. 2012. Proteksi Sistem Distribusi Tenaga Listrik. Bekasi: Garamond.

[4] Jasa Pendidikan dan Pelatihan. Pengenalan Proteksi Sistem Tenaga Listrik. PT. PLN (Persero) Unit Diklat Semarang

[5] VTScada Software. SCADA System Requirements.Tersedia:https://www.trihedra 1.com/

[6] A. Hooshyar and R. Iravani, Microgrid Protection, Proc. IEEE, 2017.

[7] J. Schönberger, S. Round, and R. Duke, Autonomous load shedding in a nanogrid using DC bus signalling, in IECON Proceedings (Industrial Electronics Conference), 2006. 